Nepal Agric. Res. J. Vol. 9, 2009

\title{
Effect of NPK on Vegetative Growth and Yield of Desiree and Kufri Sindhuri Potato
}

\author{
Ram C. Adhikari \\ National Potato Research Program, NARC, Khumaltar, Lalitpur, Nepal
}

\begin{abstract}
A field experiment was carried out to assess the effect of NPK on vegetative growth and yield of potato cultivars; Kufri Sindhuri and Desiree at different nutrient levels $(0: 0: 0, \quad 50: 50: 50, \quad 100: 50: 50, \quad 100: 75: 50, \quad 100: 75: 100$, 100:100:100 and 150:100:100 N, $\mathrm{P}_{2} 0_{5}$ and $\mathrm{k}_{2} 0 \mathrm{~kg} \mathrm{ha}^{-1}$ ) in sandy loam soils at Rampur, Chitwan, Nepal during 1999/2000. The experiment was laid out in a split plot design with 4 replications. Plant height, number of stems, fresh weight of stem and leaves were recorded at 15 days interval during crop growth period and tuber yield at maturity stage. Kufri Sindhuri was taller than Desiree at all the stages of plant growth. Increasing levels of NPK increased the plant height by 15-42 percent. The levels of NPK imparted to a significant effect on fresh weight of leaves and stems at each successive stages of crop growth. Kufri Sindhuri responded nitrogen up to $150 \mathrm{~kg} \mathrm{ha}^{-1}$ while Desiree yielded higher at 100:100:100 kg NPK ha- ${ }^{-1}$. The yield increase of potato tuber was associated with increase in the plant height, fresh weight of leaves and stems as a result of applied NPK.
\end{abstract}

Key words: Desiree, fresh weight, Kufri Sindhuri, nutrients, tuber yield

\section{INTRODUCTION}

Potato (Solanum tuberosum L.) is one of the most productive food crops when considered in terms of yield per unit area and per unit time. In Nepal, potato is ranked as the fourth most important crop (APP 1995). It is a staple food in high hills where as it is used as major vegetable in other areas. It is, therefore not only a major food crop, but also an income generating one.

The potato plant consumes high level of nutrients during a short growth period (90 days). Variations in soil fertility affect on several characters that influence the growth and yield (Pushkarnath 1976). Good vegetative growth and tuberisation, which lead to good yield, are possible only when adequate quantities of mineral nutrients are supplied (Benepal 1967). One ton of potato tubers remove $5 \mathrm{~kg} \mathrm{~N}$, $1.8 \mathrm{~kg}, \mathrm{P}_{2} \mathrm{O}_{5}$ and $9 \mathrm{~kg} \mathrm{~K} \mathrm{~K}_{2}$ (Shnek 1994). Significant response to NPK application on potato crops has also been reported by Singh and Singh (1995) and Singh et al (1993).

It is well known that even in the same growing condition, cultivars differ in their yield performance. Similarly vegetative growth and yield performance of cultivar varies depending on the soil and climatic condition (Pushkarnath 1976). Significant potato responses to NPK application have been reported by various workers in different agro-climatic condition and optimum dose of NPK varied 
with the soil and potato varieties (Singh and Singh 1995, Maity and Arora 1980). Response of potato to NPK in soil of Chitwan had already been reported (Adhikari et al 1998-1999, Basnet et al 20002001) but there was little information on the effect of nutrient in relation to different growth stages of potato. Kufri Sindhuri and Desiree are popular potato cultivars in Tarai and inner Tarai. The present investigation is therefore an attempt to study the effect of various levels of NPK for these recommended potato cultivars on their vegetative growth and yield in Chitwan conditions.

\section{MATERIALS AND METHODS}

The experiment was carried out during 1999/2000 in the sandy loam soil at Rampur, Chitwan. Before planting the soil $\mathrm{pH}$ was 4.8 to 5.2 and organic matter varied from 2.55 to 3.22 percent. The $\mathrm{N}, \mathrm{P}_{2} \mathrm{O}_{5}$ and $\mathrm{K}_{2} \mathrm{O}$ contents in $20-\mathrm{cm}$ layer of soil were 2400 to $2800,96.54$ to 108.58 and 211.87 to $277.76 \mathrm{~kg}$ respectively.

The experiment was laid out in a split plot design with 4 replications. Potato cultivars, Desiree and Kufri Sindhuri were selected as main plot. Seven different combination of NPK ie 0:0:0 50:50:50, 100:50:50, 100:75:50, 100:75:100, 100:100:100 and 150:100:100 $\mathrm{kg} \mathrm{ha}^{-1}$, respectively were taken as sub-plots. Individual sub-plot was consisted of $4.2-\times 2.5-\mathrm{m}$ with seven rows, each of which maintained 10 plants. Half dose of $\mathrm{N}$ and full dose of $\mathrm{P}$ and $\mathrm{K}$ were applied in furrows and mixed with soil thoroughly at planting time. The remaining half dose of $\mathrm{N}$ was topdressed at the time of earthing-up after 5 weeks of planting. The sources of fertilizers were di-ammonium phosphate (18:46:0), urea (46:0:0) and Muriate of potash (0:0:60). Well-sprouted disease free tubers of Kufri Sindhuri and Desiree weighing approximately $40-50 \mathrm{~g}$ were planted at $60 \mathrm{~cm}$ row distance and 25 $\mathrm{cm}$ plant-to-plant spacing within rows. Two rows in each side of the subplot left for boarder rows. The tubers of both cultivars were planted on 2 November 1999.

The crop was irrigated after 45 days of planting through furrow method. Two sprays of Moncozeb (Dithane M-45) and one spray of Metalaxyl (Krilaxyl) were alternatively used to control the late blight disease during first fortnight of January when the environment was conducive for late blight pathogens. Weeding, earthing up and other cultural practices were carried out as per the recommended practices.

One month after planting, three plants were uprooted from each sub plot on 30, 45, 60 and 75 days after planting (DAP). These plants were separated into leaves, stems, and tubers and weighed immediately for recording the fresh weights. Observations on plant height $(\mathrm{cm})$, number of stems plant $^{-1}$ was recorded on randomly selected plants in each sub-plot. The cultivars, Desiree and Kufri Sindhuri were harvested on 3 and 28 Feb 2000, respectively. The data were analyzed following the procedure as described by Gomez and Gomez (1984). LSD test was used to compare the means among the treatments.

\section{RESULTS AND DISCUSSION}

\section{Effect on germination}

In general fertilizer levels had negligible influence on germination. Treatments having 100:100:100 NPK kg ha ${ }^{-1}$ had non-uniform germination in the initial stages as compared to other treatments, but by the time when the crop reached 30 days of planting, about 95 percent germination was observed in most of the plots (data not shown). Early and uniform germination was observed in control plots. It was also observed that increasing levels of fertilizer delayed the emergence of tubers. 


\section{Effect on plant height}

There was significant effect of NPK levels on height of plant over their zero level except at 30 DAP (Table 1). Significant increase in plant height was recorded up to the application of 100:50:50 NPK $\mathrm{kg} \mathrm{ha}^{-1}$. Kufri Sindhuri was significantly taller than Desiree at all the stages of plant growth. Increasing levels of nutrients increased plant height by 15-42 percent as compared to zero level. This is because relatively high dose of nitrogen application results in vigorous growth of the plant. Madhikarmy (1979) and Sharma and Upadhaya (1993) have also reported similar result. Increasing $\mathrm{P}$ and $\mathrm{K}$ rates had no effect on plant height at all the stages of plant growth. Jagirdar et al (1984) and Singh et al (1993) reported that increase in the level of P and K had no effect on plant height. High soil fertility and nitrogen application results in vigorous growth of the plant (Sharma and Upadhaya 1993).

\section{Effect on number of stem}

The number of stems per hill mostly depends upon varietal character. However in the present study, fertilizer levels did not show significant effect on the number of stems. Long duration (120 days) variety, Kufri Sindhuri had significantly more number of stems than the short duration (90 days) Desiree at later stage of plant growth (60 and 75 DAP) (Table 2). Sharma and Singh (1988) and Nandekar et al (1991) also showed that none of the nutrients applied could affect the number of stems significantly.

Table 1. Effect of NPK on plant height $(\mathrm{cm})$ at different dates of observation at Rampur, Chitwan, 1999/2000

\begin{tabular}{lcccc}
\hline \multirow{2}{*}{ Treatment } & \multicolumn{4}{c}{ Days after planting } \\
\cline { 2 - 5 } & 30 & 45 & 60 & 75 \\
\hline Variety (V) & & & & \\
Kufri Sinduri & 22.18 & 60.70 & 71.20 & 74.20 \\
Desiree & 18.65 & 48.70 & 56.30 & 58.20 \\
F-test & $*$ & $* *$ & $* *$ & $* *$ \\
LSD $(0.05)$ & 1.80 & 4.14 & 5.04 & 5.02 \\
\hline Nutrient $(\mathrm{N})\left(\mathrm{N}: \mathrm{P}_{2} 0_{5}: \mathrm{K}_{2} 0\right), \mathrm{kg}$ & & & & \\
ha ${ }^{-1}$ & & & & \\
$0: 00: 00$ & 21.80 & 37.20 & 45.40 & 46.80 \\
$50: 50: 50$ & 20.96 & 48.10 & 57.50 & 51.50 \\
$100: 50: 50$ & 20.53 & 60.20 & 68.70 & 71.30 \\
$100: 75: 50$ & 20.74 & 58.60 & 67.80 & 70.80 \\
$100: 75: 100$ & 20.01 & 58.30 & 67.50 & 70.60 \\
$100: 100: 100$ & 18.13 & 58.70 & 67.10 & 69.90 \\
$150: 100: 100$ & 20.74 & 61.80 & 72.20 & 74.20 \\
F-test & $\mathrm{ns}$ & $* *$ & $* *$ & $* *$ \\
LSD $(0.05)$ & & 3.81 & 4.43 & 4.27 \\
\hline Interaction $(\mathrm{V} \times \mathrm{N})$ & $\mathrm{ns}$ & $\mathrm{ns}$ & $\mathrm{ns}$ & $\mathrm{ns}$ \\
\hline
\end{tabular}

ns, not significant. ${ }^{*}$, significant at $5 \%$ level. ${ }^{* *}$, significant at $1 \%$ level. 
Nepal Agric. Res. J. Vol. 9, 2009

Table 2. Effect of NPK levels on number of stem per hill in potato at Rampur, Chitwan, 1999/2000

\begin{tabular}{lrrrr}
\hline & \multicolumn{4}{c}{ Days after planting } \\
\cline { 2 - 5 } Treatment & 30 & 45 & 60 & 75 \\
\hline Variety $(\mathrm{V})$ & & & & \\
Kufri Sinduri & 4.21 & 4.35 & 4.35 & 4.49 \\
Desiree & 3.01 & 3.23 & 3.08 & 2.89 \\
F-test & $\mathrm{ns}$ & $\mathrm{ns}$ & $*$ & $*$ \\
LSD $(0.05)$ & & & 0.61 & 0.53 \\
\hline Nutrient $(\mathrm{N})\left(\mathrm{N}: \mathrm{P}_{2} 0_{5}: \mathrm{K}_{2} 0\right), \mathrm{kg}$ & $\mathrm{ns}$ & $\mathrm{ns}$ & $\mathrm{ns}$ & $\mathrm{ns}$ \\
ha $^{-1}$ & $\mathrm{~ns}$ & $\mathrm{~ns}$ & $\mathrm{~ns}$ & $\mathrm{~ns}$ \\
\hline Interaction $(\mathrm{V} \times \mathrm{N})$ & $\mathrm{ns}$ & & &
\end{tabular}

\section{Effect on fresh weight of leaves}

Leaf weight indicates the size of photosynthetic system and intercepted radiation and there is a relationship between leaf area and total tuber yield. Kufri Sindhuri had significantly higher leaf weight than Desiree at 60 and 75 DAP (Table 3). It is evident from table 3 that the levels of NPK significantly increased the fresh weight of leaves at all the growth stages except 30 DAP. Significant increase in leaf weight was recorded with the application of fertilizers 100:50:50 NPK kg ha ${ }^{-1}$ as compared to zero level (control). Leaf weight was increased significantly from 45 to 75 days. Sharma and Arora (1987) have reported similar results. Increase in $\mathrm{P}$ and $\mathrm{K}$ had no prominent effect on fresh weight of leaves. Puskarnath (1976) and Taya et al (1994) also reported that the rates of increase in top growth and leaf weight are directly related to the level of $\mathrm{N}$ applied. Increase in $\mathrm{P}$ and K had no prominent effect on fresh weight of leaves. Puskarnath (1976) and Taya et al (1994) also reported that the rates of increase in top growth and leaf weight are directly related to the level of $\mathrm{N}$ applied.

Interaction of nutrients in soils and plants is an important factor in determining the yield of crops. Since nitrogen is required for the formation of chlorophyll and phosphorus for cell division and elongation (Basnet et al 2000-2001). Interaction effect of fertilizer levels and cultivars on leaf weight was also significant at all the observations except 30 DAP (Table 3). Potato varieties differ greatly in their to NPK application indicating a strong interaction of varieties with NPK application with regards to their leaf weight at different growth stages. Kumar et al (1991) and Grewal and Trehan (1993) reported that short duration varieties response less to NPK during different growth stages than long duration varieties. In Kufri Sinduri increasing level of nitrogen up to $100 \mathrm{~kg} \mathrm{ha}^{-1}$ at 45, 60 and 75 days of planting significantly increased in the leaf weight. But increasing level of $\mathrm{P}$ up to $75 \mathrm{~kg} \mathrm{ha}^{-1}$ had no effect on leaf weight of Kufri Sinduri except 75 DAP. Increasing level of K had little effect on weight of leaf at all the growth stage. Grewal and Trehan (1993) also reported similar results. Desiree is a short duration variety and less responsive to NPK at different growth stages as compared to Kufri Sinduri. The increment of nitrogen dose from $100-150 \mathrm{~kg} \mathrm{ha}^{-1}$ had no effect on leaf weight at all the growth stages. Increasing P rate had no prominent effect on leaf weight of Desiree at all the growth stages whereas K level up to $100 \mathrm{~kg} \mathrm{ha}^{-1}$ had a little effect during 45 and 75 DAP. 


\section{Effect on fresh weight of stems}

Significant cultivar difference was also found on stem weight during later stage of crop growth (60 and 75 DAP). The levels of NPK imparted a significant effect on fresh weight of stem at each successive stages of crop growth except 30 DAP (Table 4). In the beginning, the increase in fresh weight was more but it declined after 60 DAP. The increase in the fresh weight of stem by NPK application is due to its association with the metabolic activities of the plant that brings about better growth (Singh and Singh 1995). Nitrogen and phosphorus had increasing effect on fresh weight of stems. Soltanpour and Cole (1978) reported that application of N and P fertilizers to the soil increased the fresh weights of stems. Taya et al (1994) reported that K has not significant effect on fresh weight of stems. Analysis of variance showed a non-significant interaction between cultivars and fertilizer levels at early stages of plant growth (30 and 45 DAP). The long duration variety Kufri Sinduri had significantly response to $\mathrm{N}$ and $\mathrm{P}$ on stem weight during 60 and 75 DAP where as application of $\mathrm{K}$ had no apparent effect on Deiree at all the growth stages. The results indicated that potato varieties differ greatly in their response to NPK application with regards to their stem weight during 60 and 75 DAP.

\section{Effect on tuber yield}

Tuber yield calculated on per plot basis ranged from 25.7 to 35.7 and 14.9 to $21.1 \mathrm{t} \mathrm{ha}^{-1}$ in Kufri Sindhuri and Desiree, respectively (Figure 1). The highest tuber yield of Kufri Sindhuri and Desiree ie 35.3 and 21.1 t ha ${ }^{-1}$ was obtained at 150:100:100 and 100:100:100 NPK kg ha ${ }^{-1}$ respectively. Significant increment in tuber yield was found up to the application of 100:50:50 NPK kg ha' ${ }^{-1}$. Long duration variety, Kufri Sinduri is high yielder than Desiree. Kufri Sinduri was found more responsive to nitrogen than Desiree at Rampur, Chitwan.

Table 3. Effect of NPK on fresh weight of leaves (g hill ${ }^{-1}$ ) at Rampur, Chitwan, 1999/2000

\begin{tabular}{|c|c|c|c|c|}
\hline \multirow{2}{*}{ Treatment } & \multicolumn{4}{|c|}{ Days after planting } \\
\hline & 30 & 45 & 60 & 75 \\
\hline \multicolumn{5}{|l|}{ Variety $(\mathrm{V})$} \\
\hline Kufri Sinduri & 36.55 & 140.26 & 288.41 & 273.67 \\
\hline Desiree & 34.67 & 97.69 & 139.32 & 131.79 \\
\hline F-test & \multirow{2}{*}{\multicolumn{2}{|c|}{$\mathrm{ns}$}} & $* *$ & $* *$ \\
\hline $\operatorname{LSD}(0.05)$ & & & 58.45 & 55.79 \\
\hline \multicolumn{5}{|c|}{$\begin{array}{l}\text { Nutrient }(\mathrm{N})\left(\mathrm{N}: \mathrm{P}_{2} 0_{5}: \mathrm{K}_{2} \mathrm{O}\right), \mathrm{kg} \\
\mathrm{ha}^{-1}\end{array}$} \\
\hline 0:00:00 & 34.71 & 74.51 & 141.76 & 128.99 \\
\hline $50: 50: 50$ & 34.95 & 111.85 & 175.77 & 176.56 \\
\hline $100: 50: 50$ & 37.12 & 127.99 & 225.44 & 195.51 \\
\hline $100: 75: 50$ & 35.30 & 123.36 & 228.75 & 222.68 \\
\hline 100:75:100 & 34.35 & 127.21 & 236.68 & 221.87 \\
\hline $100: 100: 100$ & 36.30 & 134.91 & 227.50 & 221.38 \\
\hline 150:100:100 & 36.54 & 132.99 & 261.17 & 252.13 \\
\hline F-test & $\mathrm{ns}$ & $* *$ & ** & ** \\
\hline $\operatorname{LSD}(0.05)$ & & 17.08 & 33.32 & 33.79 \\
\hline
\end{tabular}

Interaction $(\mathrm{V} \times \mathrm{N})$ 


\begin{tabular}{lrrrr}
$\mathrm{KS} \times 0: 0: 0$ & 36.30 & 78.09 & 200.59 & 175.56 \\
$\mathrm{KS} \times 50: 50: 50$ & 36.04 & 125.50 & 230.16 & 238.25 \\
$\mathrm{KS} \times 100: 50: 50$ & 38.29 & 155.79 & 290.67 & 257.67 \\
$\mathrm{KS} \times 100: 75: 50$ & 35.78 & 155.00 & 306.57 & 317.16 \\
$\mathrm{KS} \times 100: 75: 100$ & 36.07 & 152.00 & 320.90 & 301.54 \\
$\mathrm{KS} \times 100: 100: 100$ & 36.36 & 159.37 & 300.00 & 273.13 \\
$\mathrm{KS} \times 150: 100: 100$ & 37.02 & 156.08 & 370.12 & 352.41 \\
$\mathrm{De} \times 0: 0: 0$ & 33.13 & 70.93 & 82.93 & 82.42 \\
$\mathrm{De} \times 50: 50: 50$ & 33.86 & 98.20 & 121.38 & 114.88 \\
$\mathrm{De} \times 100: 50: 50$ & 35.96 & 100.19 & 160.21 & 133.36 \\
$\mathrm{De} \times 100: 75: 50$ & 34.81 & 91.73 & 150.93 & 128.21 \\
$\mathrm{De} \times 100: 75: 100$ & 32.63 & 102.41 & 152.47 & 142.21 \\
$\mathrm{De} \times 100: 100: 100$ & 36.24 & 110.46 & 155.00 & 169.63 \\
$\mathrm{De} \times 150: 100: 100$ & 36.02 & 109.90 & 152.32 & 151.84 \\
$\mathrm{~F}-\mathrm{test}$ & $\mathrm{ns}$ & $* *$ & & $* *$ \\
$\mathrm{LSD}(0.05)$ & & 24.15 & 47.12 & 47.79 \\
\hline$K S, K u f 1 S i n d h u r i$ \\
\hline
\end{tabular}

KS, Kufri Sindhuri. De, Desiree. ns, not significant. **, significant at 1\% level.

The initial soil analysis showed high amount of organic matter, nitrogen, and phosphorus and medium amount of potassium in the soil samples of the experimental plots. The value above $1.29 \%$ organic matter, the available total NPK more than 543, 22 and $333 \mathrm{~kg} \mathrm{ha}^{-1}$ respectively considered as rich amounts in soils (Arora et al 1979). In the experimental plot nitrogen and phosphorus were higher than these values. High nutrient status of the experimental plot played a significant role in increasing the fertility status of the soils. Kufri Sindhuri responded nitrogen was up to $150 \mathrm{~kg} \mathrm{ha}^{-1}$, while Desiree yield started to decline slightly beyond N $100 \mathrm{~kg} \mathrm{ha}^{-1}$. Nitrogen assist to increase leaf area, leaf weight, stem weight, plant height. The increase in the yield of potato tubers was found to be associated with increase in the plant height, fresh weight of leaves and stems as a result of applied of NPK. Sharma and Singh (1988) and Rykbost et al (1993) reported the increase in the yield of potato tubers due to NPK application. Significant increasing yield of Kufri Sindhuri and Desiree was recorded with 100:50:50 NPK kg ha ${ }^{-1}$ with the ration of 1:0.5:0.5 (Figure 1).

The finding of this study suggests that in sandy loam soils of Rampur, Chitwan potato cultivar Kufri Sindhuri yields high at higher level of N (150 kg/ha) while Desiree yields higher at 100:100:100 NPK kg ha ${ }^{-1}$ of mineral nutrients.

Table 4. Effect of NPK on fresh weight of stems (g hill ${ }^{-1}$ ) at Rampur, Chitwan, $1999 / 2000$

\begin{tabular}{lrrrr}
\hline \multirow{2}{*}{ Treatment } & \multicolumn{4}{c}{ Days after planting } \\
\cline { 2 - 5 } & 30 & 45 & 60 & 75 \\
\hline Variety (V) & & & & \\
Kufri Sinduri & 18.75 & 78.25 & 145.21 & 140.38 \\
Desiree & 12.91 & 52.60 & 69.02 & 65.11 \\
F-test & ns & ns & $* *$ & $* *$ \\
LSD (0.05) & & & 41.25 & 49.30 \\
\hline
\end{tabular}

Nutrient $(\mathrm{N})\left(\mathrm{N}: \mathrm{P}_{2} 0_{5}: \mathrm{K}_{2} 0\right), \mathrm{kg}$

$\mathrm{ha}^{-1}$ 


\begin{tabular}{|c|c|c|c|c|}
\hline 0:00:00 & 15.00 & 39.76 & 55.63 & 51.52 \\
\hline $50: 50: 50$ & 16.69 & 56.42 & 88.09 & 86.40 \\
\hline $100: 50: 50$ & 16.77 & 72.33 & 109.25 & 98.10 \\
\hline $100: 75: 50$ & 16.38 & 72.30 & 120.23 & 118.48 \\
\hline 100:75:100 & 15.42 & 71.46 & 116.53 & 111.56 \\
\hline $100: 100: 100$ & 15.56 & 70.38 & 125.19 & 118.44 \\
\hline $150: 100: 100$ & 15.00 & 75.30 & 134.86 & 134.71 \\
\hline F-test & ns & $*$ & $* *$ & $* *$ \\
\hline $\operatorname{LSD}(0.05)$ & & 9.19 & 17.30 & 16.25 \\
\hline \multicolumn{5}{|l|}{ Interaction $(\mathrm{V} \times \mathrm{N})$} \\
\hline $\mathrm{KS} \times 0: 0: 0$ & 17.52 & 49.29 & 74.93 & 72.54 \\
\hline $\mathrm{KS} \times 50: 50: 50$ & 20.50 & 69.00 & 122.37 & 117.52 \\
\hline $\mathrm{KS} \times 100: 50: 50$ & 20.54 & 86.40 & 141.64 & 126.09 \\
\hline $\mathrm{KS} \times 100: 75: 50$ & 19.04 & 84.50 & 163.25 & 168.17 \\
\hline $\mathrm{KS} \times 100: 75: 100$ & 18.38 & 87.00 & 155.83 & 150.38 \\
\hline $\mathrm{KS} \times 100: 100: 100$ & 17.60 & 82.69 & 170.71 & 160.46 \\
\hline $\mathrm{KS} \times 150: 100: 100$ & 17.67 & 88.83 & 187.71 & 187.54 \\
\hline De $\times 0: 0: 0$ & 12.48 & 30.23 & 36.33 & 30.49 \\
\hline De $\times 50: 50: 50$ & 12.87 & 43.83 & 53.82 & 55.29 \\
\hline De $\times 100: 50: 50$ & 13.00 & 58.26 & 76.85 & 70.12 \\
\hline De $\times 100: 75: 50$ & 13.71 & 60.10 & 77.21 & 68.79 \\
\hline De $\times 100: 75: 100$ & 12.56 & 55.92 & 77.23 & 72.75 \\
\hline De $\times 100: 100: 100$ & 13.52 & 58.07 & 79.67 & 76.42 \\
\hline De $\times 150: 100: 100$ & 12.33 & 61.77 & 82.02 & 81.87 \\
\hline F-test & ns & ns & $* *$ & $* *$ \\
\hline $\operatorname{LSD}(0.05)$ & & & 24.47 & 22.99 \\
\hline
\end{tabular}

KS, Kufri Sindhuri. De, Desiree. ns, not significant. *, significant at 5\% level. **, significant at $1 \%$ level. 


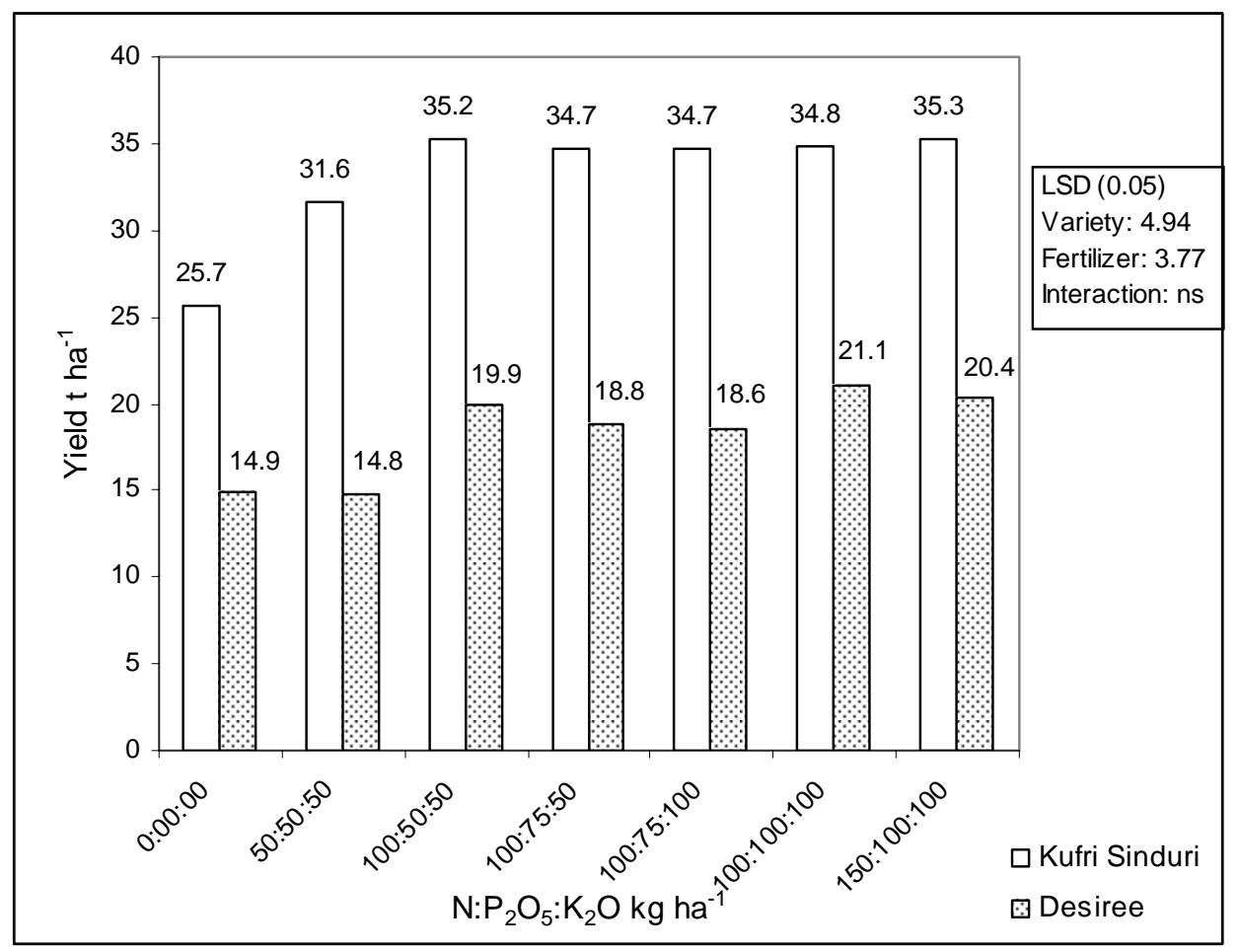

Figure 1. Effect of $N, P$ and $K$ on tuber yield of potato at Rampur, Chitwan, 1999/2000.

\section{REFERENCES}

Adhikari RC, MD Sharma, SM Shakya, G Upreti and GP Rai. 1998-1999. Effect of fertilizers on tuber size and yield of potatoes in Rampur, Chitwan. J. Inst.Agric. Anim. Sci. 21-22:85-93.

APP. 1995. Agriculture Perspective Plan. National Planning Commission, Kathmandu, Nepal. 633 p.

Arora BR, IM Chhibba and GS Sekhon.1979. Practical manual soils and waters testing for BSc (Agri) honors in soils. Department of soils, Punjab Agricultural University, Ludhiana, India. $136 \mathrm{p}$.

Basnet KB, MD Sharma and RC Adhikari. 2000-2001.Effect of different level of potash on the performance of potato under humid subtropical condition of Chitwan. J. Inst.Agric. Anim.Sci. 21-22:1-7.

Benepal PS. 1967. Inter relations among plant nutrients, application levels on yields of potatoes. Amer. Potato J. 44(6)187-194.

Gomez KA and A Gomez. 1984. Statistical procedure for agricultural research. Second Edition. John Willy and Sons, New York. 680 p. 
Grewal JS and SP Trehan. 1993. Phosphorus and potassium nutrition of potato. In: Advances in horticulture 7 (KL Chadha and JS Grewal, eds). Malhotra Publishing House, New Delhi. Pp. 260-296.

Jagirdar SAP, MH Laghari and MS Panhwar. 1984. Effect of fertilizer on growth and yield of potato. Pakistan J. Agri. Research 5(3):162-164.

Kumar R, SC Khurana and ML Pandita. 1991. Correlation studies in potato. J. Indian Potato Assoc. 18(3-4):169-171.

Madhikarmy SG. 1979. Effect of NPK fertilization on the performance of Kufri Jyoti potato (Solanum tuberosum). Nepalese J. Agric. Nepal Agricultural Association. 14:125-131.

Maity K and P. N. Arora. 1980. Effect of varieties, levels and sources of potash on potassium composition and uptake in potato. Indian J. Agron. 25(1):1-8.

Nandekar DN, TR Sharma, RC Sharma and SD Sawarkar. 1991. Fertilizer requirements of potato cv Kufri Badshah in Madya Pradesh. J. Indian Potato Assoc. 16(2/3):123-126.

Pushkarnath. 1976. Potato in sub-tropics. Orient Longman. 289 p.

Rykbost KA, NW Christensen and J Maxwell. 1993. Fertilization of russet Burbank in short-season environment. Ameri. Potato J. 70:699-708.

Sharma RC and NC Upadhaya. 1993. Nitrogen nutrition of potato. In: Advances in horticulture 7 (KL Chadha and JS Grewal, eds). Malhotra Publishing House, New Delhi. Pp. 231-259.

Sharma UC and K Singh. 1988. Response of potato N, P and K in acidic hill soil of Meghalaya. J. Indian Potato Assoc. 15(1-2):40-44.

Sharma UC and BR Arora. 1987. Effect of nitrogen, phosphorus and potassium application on yield of tubers. J. Agric. Sci. Camb.108:321-328.

Shnek M. 1994. Multi-K 13-0-46 for potatoes. Haifa Chemicals Ltd, Haifa Bay, Israel. 8 p.

Singh J, M Singh, MS Saimbni and KS Kooner. 1993. Growth and yield of potato cultivars as affected by plant density and potassium levels. J. Indian Potato Assoc. 20(3-4):279282.

Singh VN and SP Singh. 1995. Effect of levels and methods of potassium application on vegetative growth and yield of potato cv Kufri Badshah. J. Indian Potato Assoc. 22(34):118-121.

Soltanpour PN and CV Cole. 1978. Ionic Balance and growth of potatoes as affected by N plus P fertilization. Amer. Potato J. 55:549-559.

Taya JS, YS Mallik ML Pandita and SC Khurana. 1994. Fertilizer management in potato based cropping system. 1: Growth and yield of Potato. J. Indian Potato Assoc. 21(34):184-488. 